\title{
Választójog, választási rendszerek és népszavazások a közjog és a politika határán
}

\author{
Recenzió a Tanulmányok a választójog, a választási \\ rendszerek és a népszavazás aktuális kérdéseiröl \\ (szerk. Téglási András) című kötetről ${ }^{1}$
}

HORVÁTH ATTILA²

A nyolc tanulmányt felölelö kötet a választójog, a választási rendszerek és a népszavazás különböző szegmenseit tárgyalja, a magyar szabályozáson kívül a német és a szlovák választási rendszert is érintve. A nagyobb részben jogtudományi, kisebb részben pedig politikatudományi szempontú elemzések nagy hangsúlyt fektetnek a témakörrel kapcsolatos hazai és nemzetközi tapasztalatok, szabályozási modellek, kihívások és dilemmák bemutatására.

Kulcsszavak: választójog, választási rendszerek, választási eljárás, népszavazás

Suffrage, Electoral Systems and Referendum at the Border of Public Law and Politics: Review of the Book Entitled Studies on the Current Issues of Suffrage, Electoral Systems and Referendum (ed. by Téglási András)

The volume, covering eight studies, discusses the various segments of suffrage, electoral systems and referendum; in addition to the Hungarian legal regulations, it also touches upon the German and Slovak electoral systems. The analyses, mostly from the point of view of law and to a lesser extent from the point of view of political science, place great emphasis on outlining the domestic and international experiences, regulatory models, challenges and dilemmas related to the topic.

Keywords: suffrage, electoral system, electoral procedure, referendum

1 Téglási András (szerk.): Tanulmányok a választójog, a választási rendszerek és a népszavazás aktuális kérdéseiröl. Budapest, Dialóg Campus, 2019.

2 Adjunktus, Nemzeti Közszolgálati Egyetem Államtudományi és Nemzetközi Tanulmányok Kar; vezető kutató, Mádl Ferenc Összehasonlító Jogi Intézet Közjogi Kutatási Főosztály, e-mail: horvathattila@uni-nke.hu 
A Nemzeti Közszolgálati Egyetemen 2017-2018-ban működő Választás és Demokrácia Ludovika Kutatócsoport kutatási eredményeit összegző - a KÖFOP-2.1.2-VEKOP15-2016-00001 „A jó kormányzást megalapozó közszolgálat-fejlesztés” című projekt keretében megjelent - kiadvány a választójog, a választási rendszerek és a népszavazás tárgykörében született tanulmányokat tartalmaz. A szerzők között hazai és külföldi egyetemi oktatók és kutatók, gyakorlati szakemberek és PhD-hallgatók is találhatók, vagyis a témakör művelőinek széles köre járult hozzá a kötet megszületéséhez.

Amint a szerkesztői előszóból kiderül, a kutatás egyik célkitűzése az volt, hogy a magyar választójogi szabályozás és a választási rendszer átalakulását kísérő közjogi vitáknak teret adjon, ugyanis az új fejlemények egy része a magyar jogirodalomban még reflektálatlanul maradt. Tekintve, hogy a kutatás 2018 elején zárult, az ez évi országgyülési választások még nem képezhették a vizsgálódások tárgyát, azonban a 2014-es - immár az új szabályozási környezetben lebonyolított - választások tapasztalatai már számos írásban visszaköszönnek.

Ahhoz képest, hogy egy több mint 500 oldalas kiadványról van szó, mindössze nyolc tanulmányt tartalmaz a kötet, ami abból a szempontból kétségtelenül pozitívum, hogy az egyes témakörök így nagyobb terjedelemben és ennek megfelelően nagyobb alapossággal tárgyalhatók (a tanulmányok többsége 40-70 oldal körül van, ami hozzávetőlegesen 3-6 íves terjedelmet jelent).

Már a kötet tartalomjegyzékét áttekintve megállapítható, hogy a tanulmányokban keverednek a jog- és politikatudományi nézőpontok, az alapjogi és közjogi dimenziók, valamint a hazai és nemzetközi/külföldi fókuszú írások. Mindez természetesen a legkevésbé sem értékelhető negatívumként, hiszen maga a témakör is meglehetősen sok nézőpontból vizsgálható, így a tanulmányok divergenciája, sokszínűsége a kötet erényére válik.

Kukorelli István A NATO-népszavazás (1997. november 16.) címü tanulmánya a referendum közjogi és politikai kontextusát idézi fel. Ez volt az első olyan népszavazás, amely nem a rendszerváltáshoz kötődött, és egyben az utolsó, amelyet az 1989-es - időközben jelentősen átalakított - népszavazási törvény alapján rendeztek meg. Az írás rámutat a népszavazás kitűzésének bonyodalmaira (a NATOcsatlakozás kérdése „összekeveredett” az ellenzéki pártok termőföldtulajdonnal kapcsolatos népszavazási törekvéseivel) és a népszavazás eredményének megállapítása körüli jogértelmezési zavarokra. A népszavazás eredményének értékelése során a szerző - aki 1997-1999 között az Országos Választási Bizottság (OVB) elnöke volt, így közvetlenül is részese volt a folyamatoknak - az Országgyủlés elé terjesztett OVB-beszámolóból idézve kiemeli, hogy „[a] népszavazást olyan, az Alkotmánnyal ellentétes törvény alapján kellett lebonyolítani, amelynek alkotmányellenességét az Alkotmánybíróság is megállapította”. A tanulmányból plasztikusan kirajzolódik, hogy milyen komoly közjogi anomáliák övezték a NATO-referendumot, és betekintést nyerhetünk abba is, hogy - a szerző szavaival élve - „zürös jogi helyzetet” milyen jogértelmezési technikákkal lehetett áthidalni. Álláspontom szerint még több mint két évtized távlatából is nyugtalanító belegondolni, hogy a népszavazásra milyen in- 
koherens jogi szabályozás mellett került sor. Mindenesetre tiszta helyzetet csak a következő év elején elfogadott új népszavazási törvény teremtett.

A népszavazás tárgykörében íródott másik tanulmány Gáva Krisztián Történetek az Agoráról című munkája, amely a jelenlegi (2013-as) népszavazási törvény jogalkalmazási tapasztalatainak áttekintésére vállalkozik, az athéni népgyülések megidézése után kiindulópontként azt a kérdést feltéve, hogy: „Vajon napjaink népszavazási intézménye, annak a demokráciában betöltött szerepe is ilyen maradandóan bevésődik majd a közjogtörténetbe, vagy csekély gyakorlati jelentőségénél fogva a történelmi emlékezet homályába vész majd?” A szerző ezt követően a 2014-2017-es időszak tapasztalataira építve veszi számba a törvény egyes jogintézményeit. A népszavazási kezdeményezés megváltozott adminisztratív követelményeinek tárgyalása során rámutat, hogy „a korábbi évek dömpingszerủ népszavazási kezdeményezései megtépázták a népszavazás jogintézményét", így szükségessé vált a kezdeményezési feltételek racionalizálása, rendezve egyúttal az olyan kardinális problémákat is, mint például az úgynevezett párhuzamossági moratórium. A potenciális népszavazási tárgykörökkel és a kizárt tárgykörökkel kapcsolatban is számos tapasztalattal gazdagodott a jogalkalmazó (és természetesen a jogalkotó is); az írás ezeket is számba véve mutat rá a felmerülő közjogi dilemmákra. Különösen tanulságos a népszavazási kérdés egyértelműségéről szóló fejezet, amely rávilágít arra, hogy esetenként nem egyszerü feladat megtalálni az egyértelműség mint garanciális elem, valamint a választópolgári akarat érvényre juttatásának elve között. Az aláírás-ellenőrzés folyamata szintén számos gyakorlati problémát vet fel, és a szerző joggal mutat rá, hogy a jogi szabályozás több szempontból is kiegészítésre szorul. A tanulmány összegzése kiemeli, hogy a 2013-as népszavazási törvény (részben a későbbi módosítások nyomán) jelentős előrelépésként értékelhető, ugyanakkor „még mindig több pontatlanság, következetlenség szerepel a törvényben, ezek megnyugtató rendezése további garanciát jelentene a népszavazás iránti tisztelet kiterjesztésére".

A választójoggal és a választási rendszerekkel foglalkozó tanulmányok közül Mráz Ágoston Sámuel A német és a magyar választási rendszer jellemzöi és csereszabatosságának korlátjai címủ - már nem jog-, hanem politikatudományi fókuszú - írása az első. A szerző a két választási rendszer másik országban való adaptálhatóságának kérdését vizsgálja; ennek keretében először a német - „önfejlesztőként” aposztrofált - választási rendszer fejlődését tekinti át, amely köztudomásúlag a kétszavazatos vegyes rendszerek mintaadó modellje. A mai rendszer alapja lényegében az 1950-es évek eleje óta változatlan, azonban a későbbiekben számos kisebb-nagyobb reform módosította a ma is működő szisztémát, sőt további újítási elképzelések is napirenden vannak (ha nem is okvetlenül a jogalkotó részéről). Az elemzésből kiderül, hogy a választási rendszer módosítása Németországban is gyakran járt kiélezett politikaiközjogi vitákkal. A tanulmány az európai viszonylatban meglehetősen bonyolultnak ható választási rendszer müködését és következményeit a 2013-as és a 2017-es parlamenti választások példáján mutatja be, kiemelve többek között az úgynevezett szuperarányosításból fakadó visszásságokat. Ezt követően a magyar választási rendszer 
jellemzésére kerül sor, a hangsúlyt a 2011-es reformra és a 2014-es választás tapasztalataira helyezve. A szerző jobbára megértő-támogató módon viszonyul az új rendszerhez, és leszögezi, hogy „összefoglalóan megállapítható, hogy a Fidesz haszonélvezője volt a választási rendszernek a győztespremizálás, a külhoni magyarok szavazata és az egyfordulós választókerületi küzdelmek miatt”. A „Mi lett volna, ha...?” jellegü kérdésekről maga a szerző is megjegyzi, hogy ezek nem okvetlenül elfogadottak a tudomány világában, azonban ettől függetlenül érdekes gondolatkísérletnek tartom a két választási rendszer hipotetikus adaptációját a másik országra. A magyar rendszer Németországra való „ráhúzása”, illetve a német megoldásnak a 2014-es hazai választásokra történő alkalmazása természetesen számos módszertani kompromisszummal jár, mindenesetre az egyértelmủen kirajzolódott a vizsgálatokból, hogy az előbbi esetben a CDU/CSU-nak 2013-ban és 2017-ben is abszolút többsége lett volna a Bundestagban; az utóbbi számítások alapján pedig megállapítható, hogy a Fidesz-KDNP 2014-ben még az abszolút többségtől is elmaradt volna.

A kötet következő tanulmánya M. Balázs Ágnes nevéhez füződik, aki A plurális választójog fogalma és megengedhetősége napjainkban című írásában egy, az egyenlő választójog alapelvét feszegető kérdést jár körül. Bár a plurális választójogra hajlamosak vagyunk jogtörténeti emlékként tekinteni, a valóságban azonban egy ma is élő megoldásról van szó, amely többnyire nem manifeszt módon jelentkezik az egyes országokban, de néhol explicit módon is létezhet (lásd például Szlovéniát, amelyre külön ki is tér a tanulmány). A szerző elsőként a plurális választójog értelmezését végzi el, rámutatva, hogy a fogalom tágabb és szűkebb módon is megragadható, és esetenként burkolt formában is jelentkezhet. Az elméleti háttér tisztázása során nyomon követhetjük a teóriával kapcsolatos vitákat, majd a nemzetközi egyezmények és szervek kapcsolódó rendelkezéseinek a feltárására kerül sor. A témakörnek értelemszerủen megvannak a hazai vonatkozásai is - ebből a szempontból mindenekelőtt a hazai nemzetiségek és a külhoni magyarok választójoga érdemel figyelmet. A szerző az utóbbi kérdést vizsgálja alaposabban - egyben példásan többoldalúan -, teret engedve a fennálló jogi szabályozással kapcsolatban felmerülő tudományos kritikáknak is. Törökország példája arra mutat rá, hogy a külhoni választópolgárok egy kétszavazatos, vegyes rendszerbe való „integrálása” nemcsak hazánkban járt közjogi vitákkal. A tanulmány végezetül egy másik rendkívül megosztó, de annál izgalmasabb kérdésre, a családi választójogra is kitér, ugyanis ez az - egyelőre csak elméletben létező - megoldás is értelmezhető a plurális választójog felől közelítve.

A kötet külföldi szerzői, Ladislav Orosz és Erik Štenpien A Szlovák Köztársaság választójoga - az inspiráció lehetséges forrása címủ tanulmányukkal járultak hozzá a kutatáshoz. A nagyívü, több mint 70 oldalas írás egy átfogó, a választójog és a választási rendszer anyagi és eljárásjogi kérdéseire is kitérő, a parlamenti, az önkormányzati, valamint az államfőválasztásokat is érintő áttekintést nyújt a témakör szlovákiai vonatkozásairól. Magyar szemmel olvasva a szlovák kollégák tanulmánya azért is különösen érdekes, mert az ottani parlamenti választási rendszer szinte minden elemében különbözik a magyar megoldástól: a rendszer tisztán arányos; nincsenek 
területi választókerületek; van viszont preferenciális szavazat, illetve a jelöltállítás (ami Szlovákiában a pártok listaállítását jelenti) feltétele - a nálunk megszokott aláírásgyüjtés helyett - az úgynevezett választási kaució megfizetése. (Az államfőválasztásnál pedig a közvetlen választás jelenti a fö eltérést.) A szerzők nem pusztán a jogszabályi környezetet ismertetik, hanem tág teret szentelnek a politikai kontextusnak is, amiből világosan kirajzolódik, hogy a választási szabályok átírása mögött szinte minden esetben kimutatható a politikai (ön)érdek (erre a választási törvény 1998-as, a demokratikus ellenzéki pártok kiszorítását célzó, Mečiar-féle módosítása a legjobb példa). A szerzők az összegzésben leszögezik, hogy véleményük szerint „a Szlovák Köztársaság választójogának szabályozása kiváló minőségűnek mondható, és a nemzetközi szabványoknak megfelel”. A szlovák kollégák ezenfelül - visszautalva a tanulmány címében található „az inspiráció lehetséges forrása” kifejezésre - pontokba szedve kiemelik azon megoldásokat, amelyek álláspontjuk szerint figyelemre méltók lehetnek más országok szakértői részére is. Többek között ebben a körben említik meg az egységes választási kódexet (2014 óta Szlovákiában minden választást - államföi, parlamenti, európai parlamenti, kerületi [megyei], települési - ugyanazon törvényben szabályozza a jogalkotó, ahogyan a népszavazást is) és a preferenciális (más néven elsőbbségi) szavazást is, amely hozzájárul a választás perszonalizációjához, hiszen a választópolgároknak ezáltal arra is van befolyásuk, hogy az általuk választott párt listájáról konkrétan mely jelöltek kerüljenek be a törvényhozásba.

Kurunczi Gábor Az általános választójog elvének aktuális kihívásai címü munkája nyomán ismét az alapjogi dimenzió válik hangsúlyossá. Az előbbi tanulmányhoz hasonlóan ezúttal is egy hosszabb lélegzetvételű, 70 oldalt meghaladó írásról van szó, amely - akárcsak M. Balázs Ágnes dolgozata - szintén a választójog határait vizsgálja, ám míg az előbbi szerző a választójog egyenlőségére (pontosabban egyenlőtlenségére) fókuszált, addig Kurunczi Gábor a választójog általánosságát tárgyalja, mintegy hipotézisként leszögezve, hogy „az általános választójog bővítése mögött az esetek többségében húzódik valamilyen politikai haszonszerzési szándék vagy egyéb politikai cél”. A tanulmány kiválóan illusztrálja azt a tényt, hogy a választójog általánossága közel sem olyan kiforrott, „lezárt” alapelv, mint amilyennek elsőre tűnik, hiszen újabb és újabb kihívások érik (és itt a „kihívás” kifejezés a legkevésbé sem negatív kontextusban értelmezendő). Az általános választójog fogalma és történeti fejlődésének felvázolását követően a szerző két vizsgálati szempontra, a lakóhely követelményére, valamint a „tudatossági” korlátra helyezi a hangsúlyt. Bár természetesen mindkét aspektusnak megvan a közjogi és alapjogi relevanciája, az előbbi sokkal közvetlenebbül összefügg a politikai közösség határmegvonásának dilemmájával, így az ezt övező jogi és közéleti viták is hevesebbek. A külföldi szabályozási modellek és a hazai megoldás összevetését követően a szerző arra a következtetésre jut, hogy a jelenlegi „félszavazatos” rendszer kiállja az alkotmányosság próbáját. Ami a „tudatossági” korlátot illeti, itt nemcsak a gondnokság alatt álló választójogával összefüggő problémákra kell gondolni, hanem az életkori korlát dilemmáira is. M. Balázs Ágnes tanulmánya után ebben az írásban is felmerül a gyerekek választójoga, pontosabban a gyermekek után 
járó választójog (más elnevezéssel családi választójog). Az ezzel kapcsolatos alkotmányjogi konfliktusok és lehetséges megoldások összegzése során a szerző azt emeli ki, hogy „a gyermekek választójogának bevezetése újra és újra előkerülő kérdés, de megvalósítási nehézségei miatt máig nem alkalmazott metódus".

A Badó Katalin, Lovassy Ádám és Téglási Andrásáltal jegyzett, AzAlkotmánybíróság választásokkal kapcsolatos joggyakorlata (1990-2017) című írás a terjedelménél fogva (közel 170 oldal) akár külön kötet tárgya lehetne. A szerzők itt nem kevesebbre vállalkoztak, mint hogy - kettéválasztva az Alaptörvény előtti és utáni időszakot - a teljesség igényével áttekintsék az Alkotmánybíróság választási rendszerekkel és választójoggal kapcsolatos gyakorlatát a kezdetektől, tehát 1990-től egészen 2017-ig, a kötet lezárásának időpontjáig. Ennek megfelelően száznál is több olyan alkotmánybírósági döntést dolgoztak fel, amelyek a választójog és a választások különböző aspektusait érintették a parlamenti küszöbtől kezdve a választópolgár önrendelkezései jogán át a választási regisztrációig. Az egyes döntések bemutatásakor ismertetik az adott ügy előzményeit, majd a testület fontosabb megállapításait és az indokolás lényegét foglalják össze közérthető formában a szerzők. A kompiláció elolvasását követően érthető meg igazán, hogy a vizsgált közel három évtizedben milyen jelentős volt az Alkotmánybíróság jogfejlesztő tevékenysége, és az is igazolást nyer, hogy a testület joggyakorlatának ismerete nélkül csak igen korlátozott lehet a választójoggal és a választásokkal kapcsolatos tudásunk.

A kötet zárótanulmánya Cserny Ákos és Téglási András Választójogi változások - Jogértelmezések, álláspontok és értékelések a 2011-2017 közötti időszak egyes választási kérdéseirôl címủ tanulmánya. A szerzők célja ezúttal az, hogy egy átfogó képet adjanak a magyar választási rendszer átalakításával kapcsolatos, leginkább kifogásolt szabályozási elemekről, kitérve a magyar jogirodalomban megjelenő pro és kontra szakmai és politikai érvekre, továbbá a kapcsolódó esetjogra is. Az első vizsgálati területet az országgyủlésiképviselő-választás anyagi jogi szabályait érintő módosítások képezik, számba véve az úgynevezett győzteskompenzációval, a külhoni magyarok és a hazai nemzetiségek választójogával, valamint az egyéni választókerületek újrarajzolásával kapcsolatban felmerülő érveket és ellenérveket, illetve a különböző szakmai álláspontokat. A határon túli magyarok választójogával kapcsolatban a szerzők úgy fogalmaznak, hogy „megfontolás tárgyát képezheti a külhoniak szavazategyenlőségének biztosítása érdekében a külhoni egyéni virtuális választókerület megteremtése”. A helyhatósági választási szabályok változásáról szóló alfejezet a fővárosi közgyủlési választás reformjára fókuszál, bemutatva a módosítás alkotmányossági problémáit. A vizsgálatok ezt követően a választási eljárással kapcsolatos változásokra térnek rá, érintve többek között a jelöltállítással, a politikai hirdetések közzétételével, a kampányfinanszírozással, a kampánycsend megszüntetésével, valamint a Magyarországon kívüli szavazással kapcsolatos problémákat. Utóbbit illetően a szerzők úgy vélekednek, hogy az elektronikus szavazás valamely módjának fokozatos bevezetése jelentene megoldást. Az új, választási eljárásról szóló 2013. évi 
XXXVI. törvény (Ve.) - meglehetősen komplex - jogorvoslati rendszere külön alfejezet tárgyát képezi.

Összegzésként megerősíthető a recenzió elején tett felvetés, miszerint bár a kötetnek a népszavazások és a választások roppant nagy világán belül nincs egy kitüntetett vizsgálati fókusza, azonban ez egyáltalán nem értékelhető fogyatékosságként, hiszen a tanulmánygyủjtemény legfőbb erénye éppen az, hogy a tág értelemben vett választási témakör legkülönbözőbb szegmenseit boncolgatja, méghozzá a szakirodalom meglehetősen széles körét feldolgozva. Külön kiemelendő, hogy a szerzők - amenynyiben a témakör jellege megengedte - többoldalú megközelítésben végezték el a vizsgálatokat, helyt adva a különböző - egymásnak esetenként ellentmondó - szakmai álláspontoknak is. A tanulmányok az arányosság problémájától kezdve a családi választójogon át az ideális külhoni szavazási módozatokig számos olyan dilemmát villantottak fel, amelyek meggyőzően illusztrálják, hogy a választójog és a választási rendszerek világa is egy folyamatosan fejlődő-átalakuló terület, amelynek egyik szépségét pontosan az adja, hogy a közjogi vizsgálódások mellett számos szempontból a politikatudományi megközelítésnek is van létjogosultsága.

Mindezek alapján a recenzió tárgyát képező tanulmánygyűjtemény érdekes és értékes adalékként járul hozzá a választójoggal, a választásokkal és a népszavazásokkal kapcsolatos szakmai-közéleti diskurzusokhoz. 